\title{
Bovine Parapoxvirus: Isolation and pathogenicity studies
}

\author{
A. S. Abdel-Moneim* , S. M. Tamam \\ Department of Virology, Faculty of Veterinary Medicine, Beni-Suef University, Beni-Suef 62511, Egypt
}

\begin{abstract}
A disease characterized by papules, nodules, vesicles, pustules and ulcers on teats and udder as well as drastic drop in milk production was seen among a cattle farm in Fayoum Governorate, Egypt. A virus was isolated by inoculation of vesicle and scrap homogenate pool from infected cattle into the chorioallantoic membrane of specific pathogen free embryonated chicken eggs. The virus was identified by presence of pock lesions, intracytoplasmic inclusion bodies on the chorioallantoic membrane, polymerase chain reaction and immunohistochemistry of the inoculated membrane. A novel pathogenicity model was developed via ear pinna inoculation of Swiss mice. The virus produced vesicular and ulcerative lesions at the site of inoculation in inoculated mice. The virus identity was confirmed by the presence of intracytoplasmic viral antigens by immunohistochemistry.
\end{abstract}

The genus Parapoxvirus forms a unique genus within the subfamily Chordopoxvirinae that differentiated into five species: orf virus (ORFV), bovine papular stomatitis virus (BPSV), parapox of red deer in New Zealand (PVNZ), pseudocowpox virus (PCPV) as well as three tentative species of the genus, auzdyk disease virus, chamois contagious ecthyma virus and sealpox virus (Büchen-Osmond, 2003). Virions are enveloped, ovoid in shape and the viral genome consists of a linear double-stranded DNA $130000-150000$ nucleotides in length covalently cross-linked at the ends (Fenner, 1996).

Ruminants are the main hosts that become infected with PPV worldwide. Affected animals such as sheep, goats, and cattle develop proliferative dermatitis in the region of the mouth, teats, and skin. Humans are occasionally affected by PPV after direct contact with lesions of infected animals, with infection rates of up to $34 \%$ in individuals at risk (Buchan ,1996). The wellknown milkers' node is a typical human clinical picture observed after infection with PCPV.

Laboratory diagnosis of the disease is achieved

\footnotetext{
* Corresponding author. Tel.: +20 125705482; fax: +20822327982 .

E-mail address: a_s_abdel_moneim@yahoo.com (A.S. Abdel-Moneim).
}

by negative stain electron microscopy from scabs of affected animals where the characteristic ovoid shape of the virion is demonstrated (Wilson and Sweeny, 1970; Hiramatsu et al., 1999; Guo et al., 2004). However, the lack of an electron microscope in many veterinary diagnostic laboratories and low sensitivity of the test lead to the development of reliable diagnostic tests. The development of PCR methods for detection of parapoxvirus has met the demands for specific and sensitive laboratory diagnosis of parapoxviruses (Mazur et al., 2000; Inoshima et al., 2000, 2001, 2002; Torfason and Gunadottir, 2002; de la Concha-Bermejilo et al., 2003; Guo et al., 2003, 2004; Tryland et al., 2005). PCR assay was applied, upon a conserved ORF; B2L, in order to detect and differentiate parapox infections (Inoshima et al., 2000; Guo et al., 2004).

Recently a disease characterized by papules, nodules, vesicles and pustules, which sometimes progressed to ulcers on teats has been seen among cattle in some areas of Egypt. During the summer of 2005, the disease was seen in cattle farm in Fayoum Governorate. We have collected lesion materials for isolation of the virus from affected cattle in the field. Virological investigations were carried out to identify the isolated virus. A mice pathogenicity model was developed by ear pinna inoculation.

Materials and Methods

Embryonated chicken eggs. SPF ECE obtained from (Nile SPF, Koom Oshiem, Fayoum, Egypt) 
were used for isolation of the field isolate, serial passages and titration of the seed stock of virus.

Laboratory Animal. Eighteen 8-week-old Swiss male mice (Biological Supply Center, Theodar Bilharz Research Institute, Cairo, Egypt) were used within this study. Mice were bred conventionally, and received standard laboratory diet as well as water ad libitum.

Clinical samples. In the present study crusted scab lesions were obtained from dairy cattle farm (Fayoum Governorate, Egypt) suffering from development of teat and udder lesions with drastic drop in milk production in the affected animals. Lesions included, vesicles (Fig.1 A), papules (Fig.1 B), and ulcers (Fig.1 C,D)on teat and udder. Only young cows (after the $1^{\text {st }}$ or $2^{\text {nd }}$ parturition) were affected.

Virus Isolation in embryonayted chicken eggs. Crusted scab lesions and skin biopsy were ground in sterile phosphate buffer saline (PBS: $\mathrm{pH}$ 7.4) making up a $20 \%(\mathrm{w} / \mathrm{v})$ solution. Antibiotics mixture (penicillin $100 \mathrm{U} / \mathrm{ml}$ and streptomycin 100 $\mu \mathrm{g} / \mathrm{ml}$ ) was added. The suspension was frozen at $-20{ }^{\circ} \mathrm{C}$ and thawed three times. After centrifugation at $2000 \times \mathrm{g}$ for $10 \mathrm{~min}, 0.2 \mathrm{ml}$ of the supernatant was inoculated onto chorioallntoic membrane of specific pathogen free ECE. Inoculated ECE were incubated at $37{ }^{\circ} \mathrm{C}$ for a period of 3-5 days. CAM was examined macroscopically and microscopically.

DNA preparation. DNA was prepared from virus infected CAM homogenate using extreme Genomic DNA purification kit II (Pierce, Rockford, IL), according to the manufacturer's instructions.

Polymerase chain reaction (PCR). PCR was performed using B2L gene specific primers (forward:5' gtcgtccacgatgagcagct 3', reverse : 5' tacgtgggaagcgcetcget3') as described by (Inoshima, et al., 2000). Briefly, $10 \mu \mathrm{l}$ sample of genomic DNA preparation was placed in $50 \mu \mathrm{l}$ of the final volume of a $10 \mu \mathrm{l}$ reaction mixture containing $50 \mathrm{mM} \mathrm{KCl}, 10 \mathrm{mM}$ Tris- $\mathrm{HCl}(\mathrm{pH}$ 8.5), $1.5 \mathrm{mM} \mathrm{MgCl2,} 200 \mathrm{mM}$ of each dNTP, 100 pmol of each oligonucleotide primer and 2U TaqDNA polymerase, (Minotech, Kreta, Greece). Amplification was carried out using initial denaturation at $95^{\circ} \mathrm{C}$ for $9 \mathrm{~min}$, followed by five cycles of $94^{\circ} \mathrm{C}$ for $1 \mathrm{~min}, 50^{\circ} \mathrm{C}$ for $1 \mathrm{~min}$ and $72^{\circ} \mathrm{C}$ for $1 \mathrm{~min}$, and then 25 cycles of $94^{\circ} \mathrm{C}$ for $1 \mathrm{~min}, 55^{\circ} \mathrm{C}$ for $1 \mathrm{~min}, 72^{\circ} \mathrm{C}$ for $1 \mathrm{~min}$. and final elongation was performed at $72{ }^{\circ} \mathrm{C}$ for $7 \mathrm{~min}$.
Amplified product analysis. Ten $\mu \mathrm{l}$ of amplified product were analyzed by agarose gel electrophoresis on $2.5 \%$ ultra pure agarose, electrophoresis grade (Gibco BRL), containing $0.5 \mu \mathrm{g} / \mathrm{ml}$ ethidium bromide in TAE buffer and visualized on an UV transilluminator.

Laboratory animal inoculation. Eighteen mice were divided into two groups. Mice in group 1(12 mice $)$ were inoculated with $10 \mu \mathrm{l}\left(10^{7} \mathrm{EID}_{50} / \mathrm{ml}\right)$ by smearing after scarification of the left ear pinnae of male, adult, Swiss mice. Mice in group 2 (6 mice) were kept as a placebo and inoculated with sterile PBS by the same route. Mice ear pinnae of affected and placebo animals were examined histologically using H\&E stain as well as immunohistochemistry.

Immunohistochemistry (IHC). IHC was performed on deparaffinized sections of CAM as well as mice ear pinnae. The adopted protocol followed that previously described (Voller and Bidwell, 1986). Briefly,after deparaffinization, tissue sections were treated with 3\% hydrogen peroxide and then subjected to antigen retrieval by incubating the sections for $15 \mathrm{~min}$ at $37^{\circ} \mathrm{C}$ with 25 $\mathrm{mg} / \mathrm{ml}$ proteinase $\mathrm{K}$ (Boehringer Mannheim, Mannheim, Germany) in $10 \mathrm{mM}$ Tris, $2 \mathrm{mM}$ $\mathrm{CaCl}$, pH 7.5. Non-specific background staining was blocked by incubating the sections for $20 \mathrm{~min}$ with blocking reagent; $1 \%$ ova albumin in TBS $(\mathrm{w} / \mathrm{v})$. The sections were then incubated for $1 \mathrm{~h}$ with bovine specific serum $1 / 10$ in TBS, $1 \%$ BSA, followed by detection with horseradishperoxidase-conjugated rabbit anti-bovine IgG. After washing, diaminobenzidine (DAB) substrate, was added (Vector Laboratories). Sections were counterstained lightly with haematoxylin and coverslipped for a permanent record.

\section{Results and Discussion}

A number of procedures have been developed to detect parapoxvirus. However most of these methods are time-consuming, laborious and sometimes show lack of specificity and sensitivity with cross-reactions observed (Wittek et al., 1980; Rosenbusch and Reed, 1983; Lard et al., 1991).

PCR protocols have been described for parapoxvirus DNA detection (Inoshima et al., 2000, 2001, 2002; Torfason and Gunadottir, 2002; Guo et al., 2003, 2004; Tryland et al., 2005, Kottaridi, et al., 2006) emphasizing on the prevention of serological cross reactivity and on diagnosing ecthyma without using isolation or 

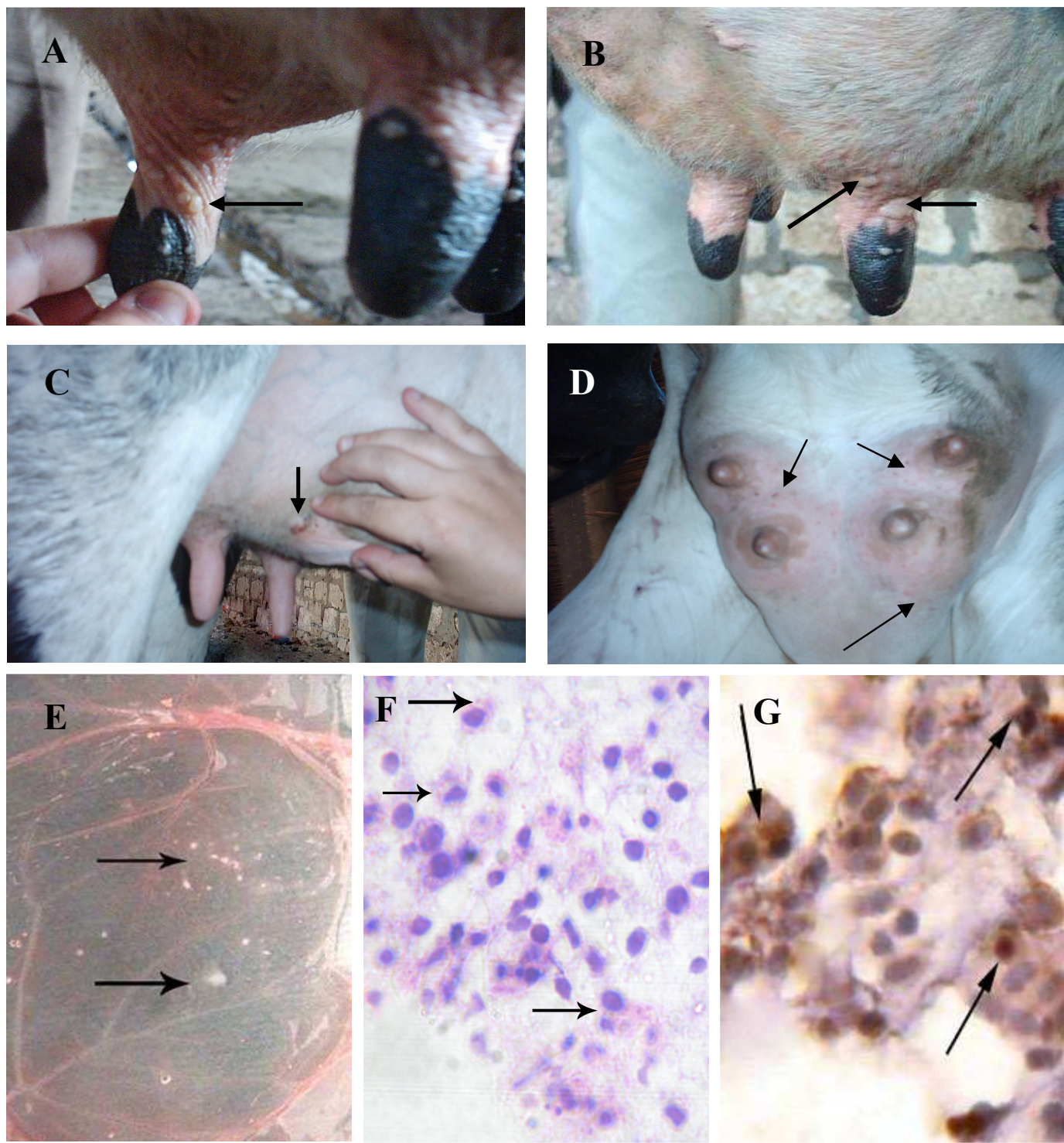

Fig. 1. Clinically affected cattle showing (A) vesicle on a teat, (B) papules on the teat and udder as well as (C, D ) ulcer on the udder. Chorioallantoic membrane of SPF ECE showing pin point pock lesions (E) and intracytoplasmic inclusion bodies in histological section of the membrane stained with $H \& E$, 40x (F). CAM sections stained immunohistochemically with anti-PPV are shown (G). 


\section{L1}

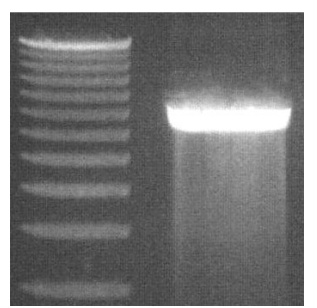

Fig. (2): Identification of parapoxvirus by PCR of B2Lgene. Specific 594 bp product was amplified from DNA of parapoxvirus. M: 100 bp molecular weight marker. Lane 1: CAM homogenate from SPF ECE inoculated with pool of crusted scab lesions and skin biopsy from clinically affected animals.

electron microscopy.

In the present study, parapoxvirus was isolated, and identified as a member of the genus parapoxvirus in the family Poxviridae on the basis of clinical signs, the presence of intracytoplasmic inclusion bodies as well as molecular characterization by PCR of $\mathrm{B} 2 \mathrm{~L}$ gene.

All parapoxviruses are immunologically closely related and cannot be distinguished in cross-neutralization tests (Wittek, et al., 1980) and distinction was achieved by DNA restriction analysis and hybridization (Wittek, et al., 1980; Gassmann, et al., 1985). Accordingly, the Egyptian strain would be a pseudocowpox virus or milker's nodule virus (Mayr, and Büttner, 1990; Fenner, 1996), a case that will be further investigated.

For virus isolation, primary bovine cells, not routinely present, are needed. Kuroda et al., 1999 isolated bovine parapoxvirus on fetal bovine lung. Primary isolation required 12 days and usually required blind passage. In addition, attempts have therefore aimed at excluding other viruses from primary cell culture, rather than isolating the parapoxvirus itself (Torfason and Guðnado' ttir, 2002). Previous report renounced the possibility of isolation of parapoxvirus on ECE (Munz and Dumbell, 1994). However we have amended this finding in the current study where virus isolation was successful in CAM of SPF-ECE. Isolation procedure has taken 3-5 days incubation in ECE however, clear lesions appeared after the $2^{\text {nd }}$ egg passage. The virus produced thickening in the chorioallantoic membrane, small pock lesions (Fig.1E) and embryonic deaths as well as multiple intracytoplasmic eosinophilic inclusion bodies in the CAM (Fig.1F). This finding was further confirmed by demonstrating intracytoplasmic viral antigens using specific bovine serum in immunohistochemistry (Fig.1 G).

Parapoxvirus proteins that interfere with the host response to infection are of interest because they provide insight into virus-host relationships and how virus overwhelms host immune response. Such studies need assessment in animal models and with this aim, a model of parapoxvirus infection based on intradermal injection of Swiss mice ear pinnae was developed and characterized. The mouse as an animal model is particularly amenable to studies of pathogenesis and immunity because of the availability of well-defined inbred strains, including a growing repertoire of targeted gene knockouts, and a wide range of immunological reagents. Accordingly, we investigate its susceptibility to bovine parapoxvirus infection. A good pathogenicity model of PPV infection should allow many parameters of infection to be assayed including clinical signs, growth of virus, infiltration of lesions and cellular and humoral immune responses. Possible sites for cutaneous inoculation not requiring shaving include the tail, footpad and ear. Tail scarification has been used in other viruses but it is difficult to assay virus or to cut histological sections from this site. Infection of the ear pinna causes less distress than footpad inoculation, has been used previously as a model for other virus infections (Hill et al., 1975; Moorhead et al., 1999; Tscharke and Smith, 1999.), and enables straightforward virological and histological analyses. Vaccinia virus has been used successfully to infect mouse ears (Tscharke and Smith 1999), whereas only virus titres were reported previously (Ikeda et al.,1991; Lee et al.,1992).Upon experimental infection of bovine parapoxvirus, mice undergo a limited infection that is well tolerated by mice. All mice developed localized lesions with no signs of systemic illness. Lesions includes vesicles and ulcers on the ear pinna (Fig. 3B, C) that heal rapidly within $24-48 \mathrm{~h}$. (Fig.3D). Such localized effects may be useful since some virus proteins may be too subtle to be detected in the context of severe infections. Furthermore, severe infections are poor models for vaccination where clinical impact must be minimized ( Briody, 1959 ) For these reasons a well - defined cutaneous model of parapoxvirus 

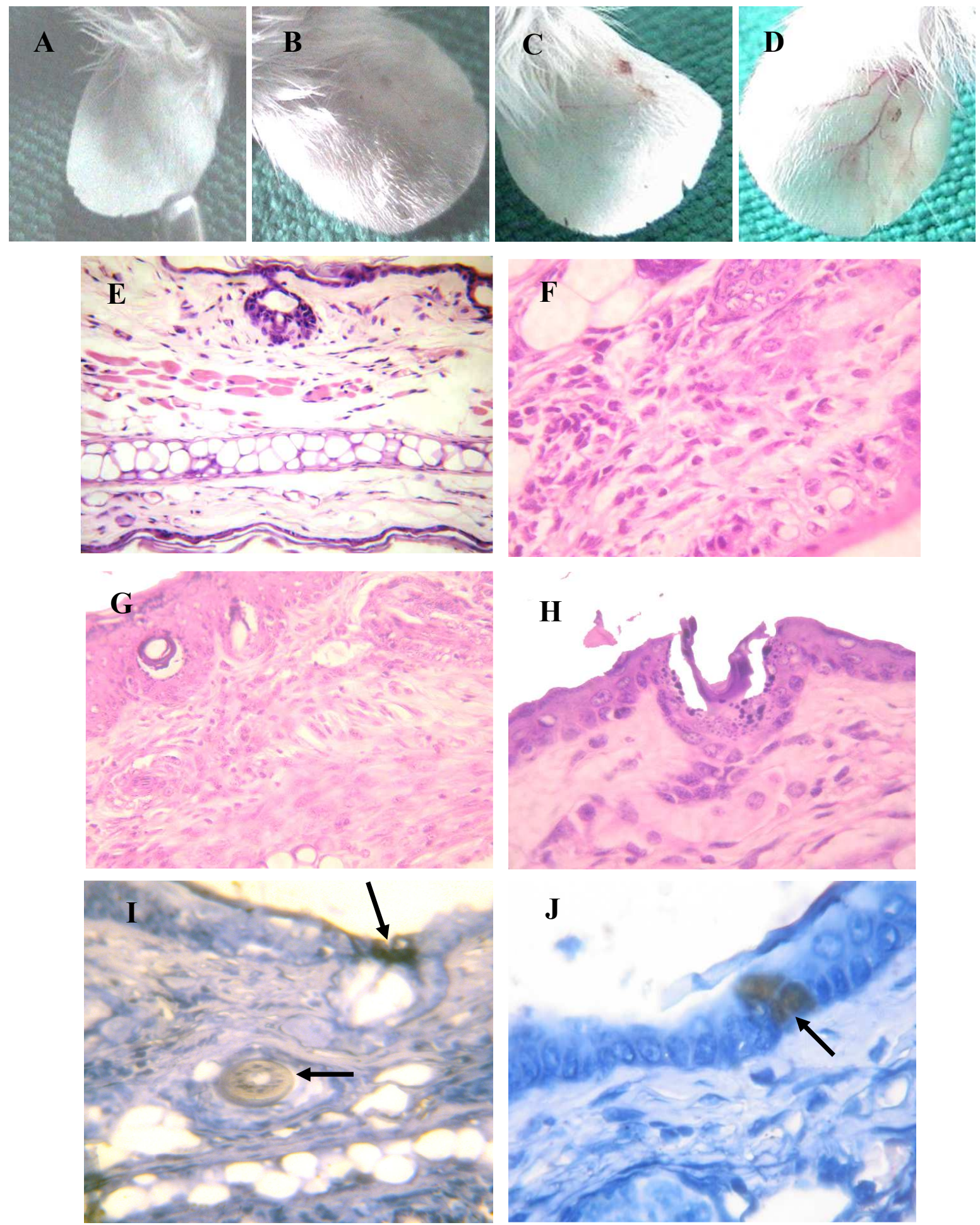

Fig. (3). Histological analysis of ear pinna infection after injection with $10^{7}$ EID $_{50}$. of parapoxvirus. Appearance of ears before in placebo (A), inoculated mice that showed vesicle (B), ulcer (C) and healed ulcer (D) haematoxylin and eosin-stained sections of placebo (E) as well as inoculated mice that showed hydropic degeneration (F) infiltration of mature and immature fibroblast $(G)$ and denuded epidermis and ulcer $(H)$. sections stained immunohistochemically with anti-PPV are shown (I,J). 
infection would be a useful tool for studying the function of PPV protein.

A histological examination of paraffin sections of ears that had been infected was undertaken after development of visible lesions (Fig. 3). A striking feature of infections was the thickening of the ear. This thickening had two probable causes : firstly, there was oedema and massive cellular infiltration of the dermis, secondly, this was probably due partly to expression of the growth factor (Buller $e t$ al., 1988). The epidermis itself was denuded, in some places (Fig.3 H). There were fibroplasias (Fig.3 G). A specific bovine serum antibody against PPV was used to detect infected cells in IHC after the appearance of visible lesions; $18^{\text {th }}$ day post experimental infection and viral antigens were found in both epidermis and dermis (Fig.3 IJ). In conclusion, we report successful isolation of PPV in ECE by CAM route in 3-5 days only. On the other hand we characterized a novel cutaneous model of PPV infection that allows many facets of pathogenesis and immunity to be examined.

\section{References}

Briody, B. (1959): Response of mice to ectromelia and vaccinia viruses. Bacteriol. Rev., 23, 61-95.

Buchan J.(1996): Characteristics of orf in a farming community in mid-Wales. BMJ, 313:203-204.

Büchen-Osmond, C. (2003): The Universal Virus Database ICTVdB. Comput. Sci. Eng., 5:16-25.

Buller, R. M. (1985): The BALB/c mouse as a model to study orthopoxviruses. Current Topics Microbiol. Immunol., 122: 148-153.

de la Concha-Bermejilo, A.; Guo, J.; Zhang, D. and Waldron, D. (2003): Severe persistent orf in young goats. J. Vet. Diagn. Invest., 15:423-431.

Fenner, F. (1996): Poxviruses. In: Fields Virology, $3^{\text {rd }}$ (Fields, B. N., Knipe, D. M. and Howley, P. M. eds). Lippincott-Raven Publishers, Philadelphia. pp. 26732702.

Gassmann, U.; Wyler, R. and Wittek, R. (1985): Analysis of parapoxvirus enomes. Arch. Virol., 83: 1731.

Guo, J.; Rasmussen, J.; Wunschmann, A. and de La Concha-Bermejillo, A., (2004): Genetic characterization of orf viruses isolated from various ruminant species of a zoo. Vet. Microbiol., 99:81-92.

Guo, J.; Zhang, Z.; Edwards, J. F.; Ermel, R.W.; Taylor, C. J. and de la Concha-Bermejillo, A. (2003): Characterization of a North American orf virus isolated from a goat with persistent, proliferative dermatitis. Virus Res., 93, 169-179.

Hill, T. J.; Field, H. J. and Blyth, W. A. (1975): Acute and recurrent infection with herpes simplex virus in the mouse: a model for studying latency and recurrent disease. J. Gen. Virol., 28:341-353.

Hiramatsu, Y.; Uno, F.; Yoshida, M.; Hatano, Y. and Nii, S. (1999): Poxvirus virions: their surface ultrastructure and interaction with the surface membrane of host cells. J. Electron Microsc., 48:937946.

Ikeda, S.; Tominaga, T. and Nishimura, C. (1991): Thy 1+asialo GM1+ dendritic epidermal cells in skin defense mechanisms of vaccinia virusinfected mice. Arch. Virol. 117:207-218.

Inoshima, Y.; Morooka, A. and Sentsui, H. (2000): Detection and diagnosis of prapoxvirus by polymerase chain reaction. J. Virol. Meth., 84: 201-208.

Inoshima, Y.; Murakami, K.; Wu, D. and Sentsui, H., (2002): Characterization of parapoxviruses circulating among wild Japanese serows (Capricornis crispus). Microbiol. Immunol., 46:583-587.

Inoshima, Y.; Murakami, K.; Yokoyama, T. and Sentsui, H., (2001): Genetic heterogeneity among parapoxviruses isolated from sheep, cattle and Japanese serows (Capricornis crispus). J. Gen. Virol., 82:12151220 .

Kottaridi, C.; Nomikou, K.; Lelli, R.; Markoulatos, P. and Manganaa, O. (2006): Laboratory diagnosis of contagious ecthyma: Comparison of different PCR protocols with virus isolation in cell culture J.Virol. Meth., 134: 119-124.

Kuroda,Y.; Yoshida, M.; Shibahara,T.; Matsui, T.; Nakane, T.; Hara, H.; Inoshima, Y. and Sentsui, H. (1999): An epidemic of parapoxvirus infection among cattle: isolation and antibody survey. J. Vet. Med. Sci., 61(7): 749-753.

Lard, S. L.; Roehrig, J. T. and Pearson, L. D. (1991): Differentiation of parapoxviruses by application of orf virus-specific monoclonal antibodies other poxvirus antigens using monoclonal antibodies against cell surface proteins. Vet. Immunol. Immunopathol., 28: 247-258.

Lee, M. S.; Roos, J. M.; McGuigan, L. C.; Smith, K. A.; Cormier, N.; Cohen, L. K.; Roberts, B. E. and Payne, L. G. (1992): Molecular attenuation of vaccinia virus : mutant generation and animal characterization. J. Virol. 66: 2617-2630.

Mayr, A. and Büttner, M. (1990): Milker's node virus. In: Virus Infections of Ruminants (Dinter, Z. and Morein, B. eds.), Elsevier Science Publishers B.V., Amsterdam. pp. 29-32.

Mazur, C.; Ferreira, I. I.; Rangel Filho, F. B. and Galler, R. (2000): Molecular characterization of Brazilian isolates of orf virus. Vet. Microbiol.,73:253259.

Moorhead, J. W.; Clayton, G. H.; Smith, R. L. and Schaack, J. (1999): A replication-incompetent adenovirus vector with the preterminal protein gene deleted efficiently transduces mouse ears. J. Virol., 73: 
1046-1053.

Munz, E. and Dumbell, K. (1994): Pseudocowpox In Infectious diseases of livestock with special reference to South Africa. J. A. W. Coetzer, G. R. Thomson, R. C. Tustin and N. P. J. Kriek (eds.)Oxford Univ. Press, pp. 625-626.

Voller, A. and Bidwell, D. (1986): Enzyme linked immunosorbent assay. In: Rose, N.R., Friedman, H., Fahey, J.L. (eds.), Manual of Clinical Laboratory Immunology. third ed. American Society for Microbiology, Washington, DC, pp. 99-109.

Rosenbusch, R. F. and Reed, D. E. (1983): Reaction of convalescent bovine antisera with strain-specific antigens of parapoxviruses. Am. J. Vet. Res., 44: 875878.

Torfason E. G. and Guðnado' ttir, S. (2002):
Polymerase chain reaction for laboratory diagnosis of orf virus infections. J. Clin. Virol., 24: 79-84

Tryland, M.; Klein, J.; Nordoy, E. S. and Blix, A. S. (2005): Isolation and partial characterization of a parapoxvirus isolated from a skin lesion of a Weddell seal. Virus Res., 108: 83-87.

Tscharke, D. C. and Smith, G. L. (1999): A model for vaccinia virus pathogenesis and immunity based on intradermal injection of mouse ear pinnae. J.Gen. Virol., 80:2751-2755.

Wilson, T. M. and Sweeny, P. R. (1970): Morphological studies of seal poxvirus. J. Wildl. Dis., 6:94-97.

Wittek, R.; Herlyn, M.; Sch"umperli, D.; Bachmann, P. A.; Mayr, A. and Wyler, R. (1980): Genetic and antigenic heterogeneity of different parapoxvirus strains. Intervirol., 13:33-41.

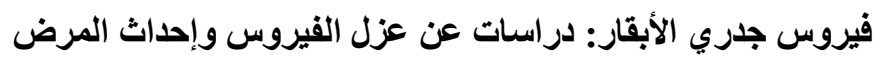



